\title{
Review Article \\ Fuel Cells: A Real Option for Unmanned Aerial Vehicles Propulsion
}

\author{
Óscar González-Espasandín, ${ }^{1}$ Teresa J. Leo, ${ }^{2}$ and Emilio Navarro-Arévalo ${ }^{3}$ \\ ${ }^{1}$ Instituto Nacional de Técnica Aeroespacial "Esteban Terradas" (INTA), Carretera Ajalvir km.4., Torrejón de Ardoz, \\ 28850 Madrid, Spain \\ ${ }^{2}$ Departamento de Sistemas Oceánicos y Navales, ETSI Navales, Universidad Politécnica de Madrid, Avenida Arco de la Victoria 4 , \\ 28040 Madrid, Spain \\ ${ }^{3}$ Departamento de Motopropulsión y Termofluidodinámica, ETSI Aeronáuticos, Universidad Politécnica de Madrid, \\ Plaza Cardenal Cisneros 3, 28040 Madrid, Spain
}

Correspondence should be addressed to Teresa J. Leo; teresa.leo.mena@upm.es

Received 31 August 2013; Accepted 11 November 2013; Published 30 January 2014

Academic Editors: K.-M. Chung and M. Yamamoto

Copyright (C) 2014 Óscar González-Espasandín et al. This is an open access article distributed under the Creative Commons Attribution License, which permits unrestricted use, distribution, and reproduction in any medium, provided the original work is properly cited.

The possibility of implementing fuel cell technology in Unmanned Aerial Vehicle (UAV) propulsion systems is considered. Potential advantages of the Proton Exchange Membrane or Polymer Electrolyte Membrane (PEMFC) and Direct Methanol Fuel Cells (DMFC), their fuels (hydrogen and methanol), and their storage systems are revised from technical and environmental standpoints. Some operating commercial applications are described. Main constraints for these kinds of fuel cells are analyzed in order to elucidate the viability of future developments. Since the low power density is the main problem of fuel cells, hybridization with electric batteries, necessary in most cases, is also explored.

\section{Introduction}

Unmanned Aerial Vehicles (UAVs), encouraged by recent technological developments, have seen a dramatic interest boost in recent years and are already considered as an integral and indispensable part of modern armed forces [1] with an increasing number of dual use and civil applications $[2,3]$. Most developed countries have already acquired UAVs or plan to do so soon. Current propulsion systems are based on different types of internal combustion engines fed by fossil fuels, but with the global energy situation, preceded by the energy crises of the 70s and strategic incentives to make alternative propulsion systems, fuel cells have started to be introduced. These have advantages in terms of endurance, efficiency, emissions, and stealth which make them ideal for UAV applications [4]. Starting from the premise that important energy and environmental problems in our society exist, the advantages and disadvantages of fuel cells as an alternative for UAV propulsion systems are going to be analyzed.

Fossil fuels pose a serious environmental and economic problem. They are the main cause for the increase of $\mathrm{CO}_{2}$ presence in the atmosphere, declared to be one of the most important culprits of global warming and the atmospheric emissions of other pollutants [7]. The current economic and financial crisis has been aggravated by the high energy prices [8], represented in Figure 1. There is therefore an urgent search for new energy policies based on the diversification of energy sources and their origin, energy saving policies, and the use of efficient energy conversion systems.

Of course, the world of aviation is not an exception to the above considerations. UAVs are in their nascent stage of development (in fact, their regulations are in process of being written), although the implementation of fuel cell propulsion systems is more advanced than in conventional aircrafts. The main reason is the fact that UAVs are unmanned, thus, 


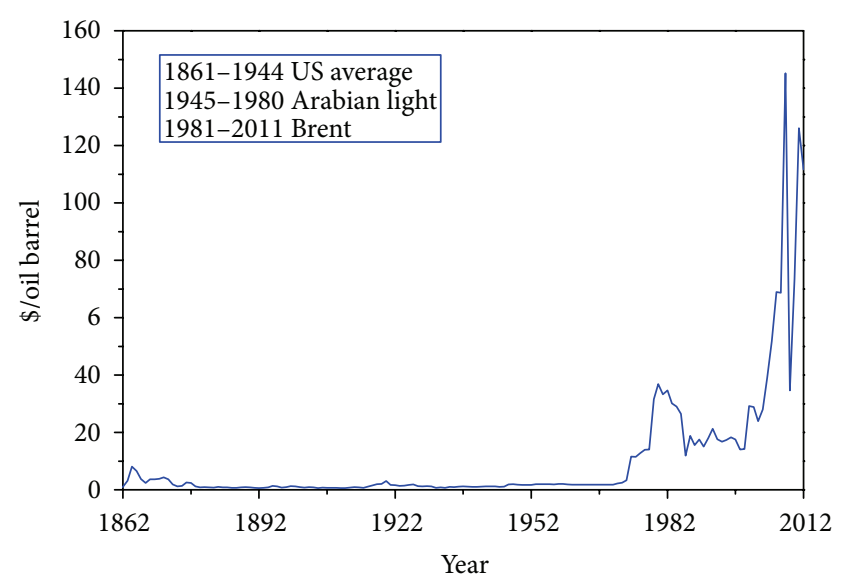

FIGURE 1: Historical world oil prices in the period 1861-2012.

weighting comparatively less and not needing the life support systems for the crew and passengers, making them ideal for this new technology. Also, fuel cells are still too heavy to propel any large aircraft; they have a lower power density when compared with conventional turbines [4]. In a military setting, there are other key operational advantages such as stealth and a lower thermal signature.

\section{UAV Propulsion Systems}

2.1. Elements of the Propulsion System. The propulsion system of a UAV consists of the following elements:

(i) energy source: chemical fuels (fossil fuels, biofuels, and chemicals), electricity, solar energy (in conjunction with photovoltaic cells), hydrogen, methanol, and energy mechanics;

(ii) storage media: tanks, batteries, capacitors, metal hydrides, and so forth;

(iii) mechanical energy converter: internal combustion engine, and fuel cell + electric motor;

(iv) lift/thrust converter: rotor, fan, propeller, jet engine, and so forth.

Lift/thrust conversion systems are closely linked to the type of aircraft (fixed wing, rotary, lighter than air, etc). In addition, propulsion systems usually include power control, rpm control, heat management system, and an auxiliary electrical power generator.

An example is the propulsion system shown in Figure 2, where the hydrogen is the energy source. The storage medium is the hydrogen tank. The mechanical energy converter is based on the combination of a fuel cell + electric motor, and the converter to lift/thrust consists of a propeller. This is the typical architecture of a fuel cell based propulsion system used in UAVs.

2.2. Types of Propulsion System in UAVs. Despite the recent boom in greener propulsion systems (electric, solar, hybrids, hydrogen internal combustion engine, etc.), the vast majority of current UAV engines are still driven by conventional internal combustion engines, normally fed with fossil fuels [19]. As an alternative to conventional propulsion, three main types of propulsion systems can be considered in UAVs:

(i) alternative thermal systems: where different thermodynamic cycles, fuel, or engine types can be used (e.g., spark-ignition reciprocating engines fuelled by gasoline);

(ii) electrical systems: where the power required is obtained through an electric motor and power is generated or stored in different ways;

(iii) hybrid systems: combining any of the systems listed above, even the same type (e.g., a combination of fuel cell and battery or Regenerative Fuel Cell Systems, RFC, which combine fuel cell, battery, and photovoltaic cells).

2.3. Hybridization. Hybridization can be achieved by combining a heat engine/electric motor with batteries [20] or fuel cell/electric motor with batteries. In either case, the need to install motors, batteries, inverters, control units, and so on makes the system heavier, bulkier, and more expensive than others. Nonetheless, it still has advantages, especially from the standpoint of a definitive adoption of alternative systems and the compensation for the low power density of fuel cells [21]. As can be seen in Figure 3, there are two possibilities: serial and parallel configurations of hybrid systems [20].

2.4. Mechanical Energy Conversion in UAVs. UAV propulsion systems can be classified by their type of mechanical energy conversion. Since internal combustion is the usual propulsion method, it is separated into jet engines and reciprocating engines according to the fuel used (petrol or diesel).

(i) Jet engines: they produce thrust and can be classified into jet engines and turbofans. Jet engines (jetturbine or turbojet, ca. $30 \mathrm{~g} /(\mathrm{kN} \cdot \mathrm{s})$ [22]) are typical of Unmanned Combat Aerial Vehicles (UCAVs). Turbofans (10-23 g/(kN.s) for small turbofans) [23] are typical in high subsonic and are more used in commercial aviation than in UAVs, notwithstanding, some UAV's such as the Global Hawk HALE UAV use them. If, instead of thrust, power is delivered to a shaft driving a propeller or rotor, they can be classified as turboprop engines (turbopropeller, ca. $0.49 \mathrm{~kg} / \mathrm{kWh}$ ) where a turbine engine is connected to a traditional propeller (e.g., Predator B UAV MALE) and turboshaft engines (ca. $0.30 \mathrm{~kg} / \mathrm{kWh}$ ) [24], typical of rotary wing aircraft. They deliver torque more smoothly and with less vibration than reciprocating engines, but are not suitable for low speed operations due to their high consumption at partial loads.

(ii) Reciprocating engines: there is a great variety attending to the combustion process (spark-ignition engines, compression ignition engines, etc.), cycle (two-stroke and four-stroke engines), intake manifold pressure (engine naturally aspirated and supercharged engines), air or water cooled, and so forth. In 


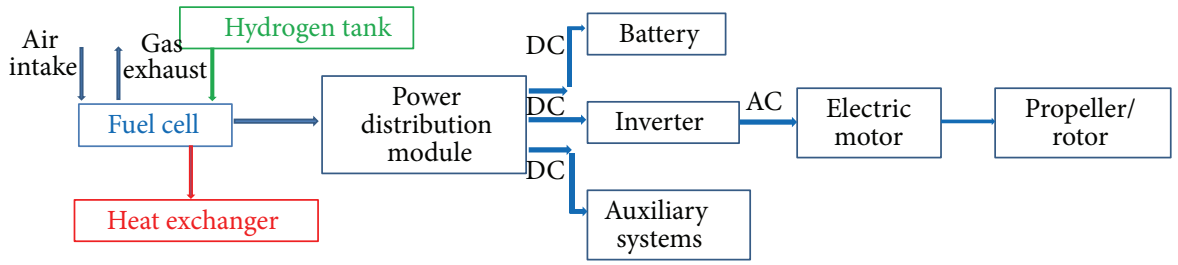

Figure 2: Diagram of the elements of a propulsion system with a mechanical energy converter based on a fuel cell + electric motor combination [5] (adapted from [6]).

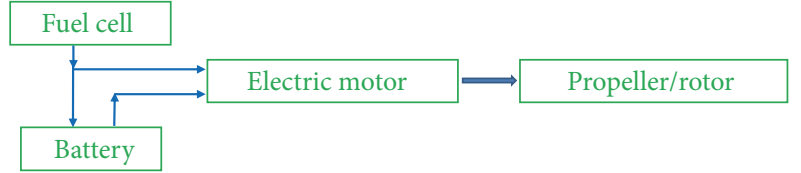

(a)

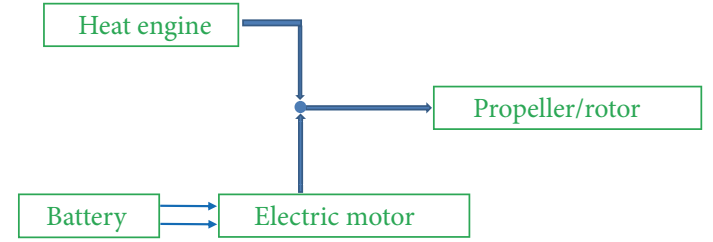

(b)

Figure 3: Diagram examples of serial (a) and parallel (b) hybrid propulsion systems [5] (adapted from [6]).

this case, the main classification is determined by the type of working cycle and its corresponding fuel, for example, aviation gasoline (piston-avgas, otto cycle, ca. $0.3 \mathrm{~kg} / \mathrm{kWh}$ ) or diesel (piston-diesel, Diesel cycle, ca. $0.24 \mathrm{~kg} / \mathrm{kWh}$ ) [25]. Among its weaknesses are the vibrations that prevent torque from being delivered smoothly. These engines are suitable for small and medium size UAVs and for short range operations, therefore Maximum Takeoff Weight (MTOW) is typically $<1,250$ kg [9] (nano-, Micro-, Mini-, Close Range (CR), Short Range (SR), Medium Range (MR), and Medium Range Endurance (MRE) UAVs are included in these categories).

(iii) Electric motors: they convert electricity into mechanical energy by moving a propeller, fan, or rotor. Electrical energy is supplied by a battery, photovoltaic or fuel cell. They have the advantage of being the quietest and having one of the lowest thermal signatures. Currently, mainly Micro- and Mini-UAVs are powered by batteries and electric motors [19]. Although they are undergoing continuous improvement, electricity demand comes not only from the engine, but also from the payload and communication systems, limiting the endurance or speed. Fuel cells and photovoltaic cells have already been tested in UAVs, but they remain far from being mature technologies.

(iv) Other types of engines: The Wankel rotary engine, which operates simply and smoothly, is gaining acceptance thanks to their sealing and torsional vibration problems being solved. Currently, Israeli Elbit Hermes 180 and Hermes 450 UAV with 28 and $38 \mathrm{~kW}$, respectively, use these types of engines; they have high durability and a specific consumption of $0.35 \mathrm{~kg} / \mathrm{kWh}$ [19].

2.5. Examples and Trends. Analysis. In order to compare different types of mechanical energy conversion components used in UAVs, in terms of power densities, technical data have been collected and represented in Table 1.

In 2008 there were 85 electric-powered UAVs whilst in 2012, there were around 232 [9] and, as can be seen in Figure 4, these follow a growing trend. "Electric" includes batteries, fuel cells, and solar energy. In Figure 5 the number of fuel cell powered UAVs has been represented. Although quite low, a steady growing trend is observed.

After observing the evolution in the use of electric motors and fuel cells in UAVs, it is important to check the breakdown (according to [9]) by size and type of propulsion system of existing UAVs in 2012, which is shown in Figure 6. As can be observed, there are many factors to consider when choosing the powerplant for a UAV. With no reference book or guide currently available, it is therefore necessary to make an exhaustive assessment of the requirements in each particular UAV.

In any case, the engine is only one component of the propulsion system. It must be mounted on the UAV and it must be provided with ignition or starting means, fuel supply, its required cooling control, and exhaust gas management if required. All these facts will influence the final choice. When comparing power and energy densities not only must the weight of the engine be taken into account, but also the weight of the energy storage system and the engine's auxiliary systems. In large UAVs, the engine will therefore have a great size and will probably come with its large associated subsystems. However, in a small UAV there will probably 
TABLE 1: Examples of power densities of different UAV powerplant components.

\begin{tabular}{|c|c|c|c|c|c|}
\hline \multicolumn{6}{|c|}{ Specifications from manufacturers' websites } \\
\hline Type & Manufacturer/model & $\begin{array}{l}\text { Weight } \\
(\mathrm{kg})\end{array}$ & $\begin{array}{c}\text { Peak power } \\
(\mathrm{kW})\end{array}$ & $\begin{array}{l}\text { Power density } \\
\quad(\mathrm{kW} / \mathrm{kg})\end{array}$ & Application \\
\hline $\begin{array}{l}\text { Reciprocating engine } \\
\text { (two-stroke) }\end{array}$ & Rotax 503 [9] & 33.2 & 37 & 1.11 & INTA SIVA UAV (SR) \\
\hline Turboprop & Honeywell TPE 331-10 [10] & 153 & 671 & 4.38 & PREDATOR B (MALE) \\
\hline Turbofan & Pratt \& Whitney Canada PW545B [11] & 347 & $18.32 \mathrm{kN}$ & 10.86 & $\begin{array}{c}\text { PREDATOR C } \\
(\text { MALE, } 741 \mathrm{~km} / \mathrm{h})\end{array}$ \\
\hline Electric motor & ElectriFly GPMG4805 Brushless DC [12] & 1.48 & 8.4 & 5.68 & $\begin{array}{c}\text { Radio-Controlled } \\
\text { Aircraft }\end{array}$ \\
\hline Lithium ion battery & ANR 26650 Cylindrical [13] & - & - & 2.60 & Portable high power \\
\hline $\mathrm{H}_{2}$ fuel cell & UTRC Gen 1 [14] & 1.78 & 1.2 & 0.675 & Helicopter mini-UAV \\
\hline $\mathrm{H}_{2}$ fuel cell & Protonex Ion Tiger UAV (NRL) [15] & 1 & 0.550 & 0.550 & Fixed-wing CR UAV \\
\hline Solar array & Several Manufacturers [16] & - & - & 0.06 & Spacecraft Applications \\
\hline Wankel & O.S. Engines 49-PI Type II 4.97 cc [17] & 0.333 & 0.934 & 2.8 & UAV Wankel engine \\
\hline
\end{tabular}

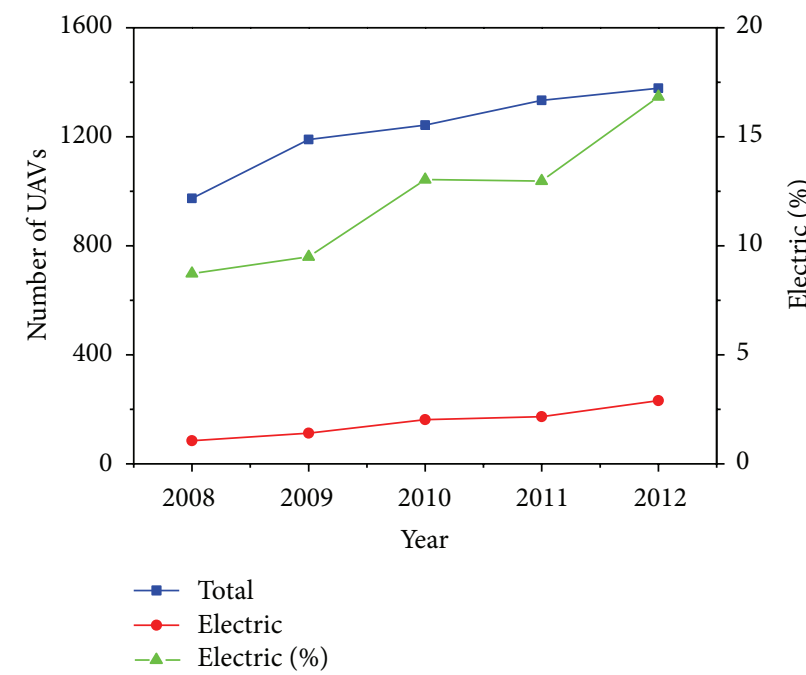

FIGURE 4: 2008-2012 evolution with \% electric UAVs trend.

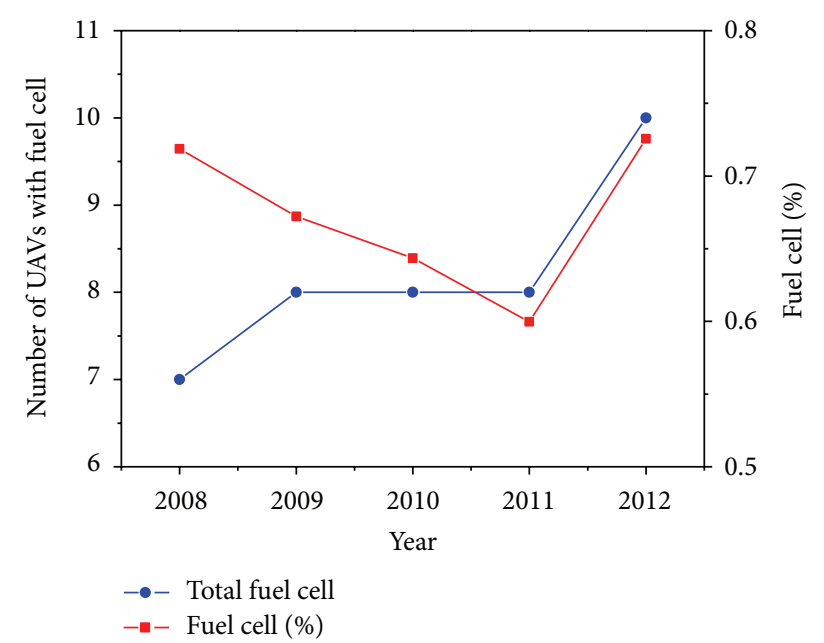

FIGURE 5: 2008-2012 evolution with \% fuel cell UAVs trend.

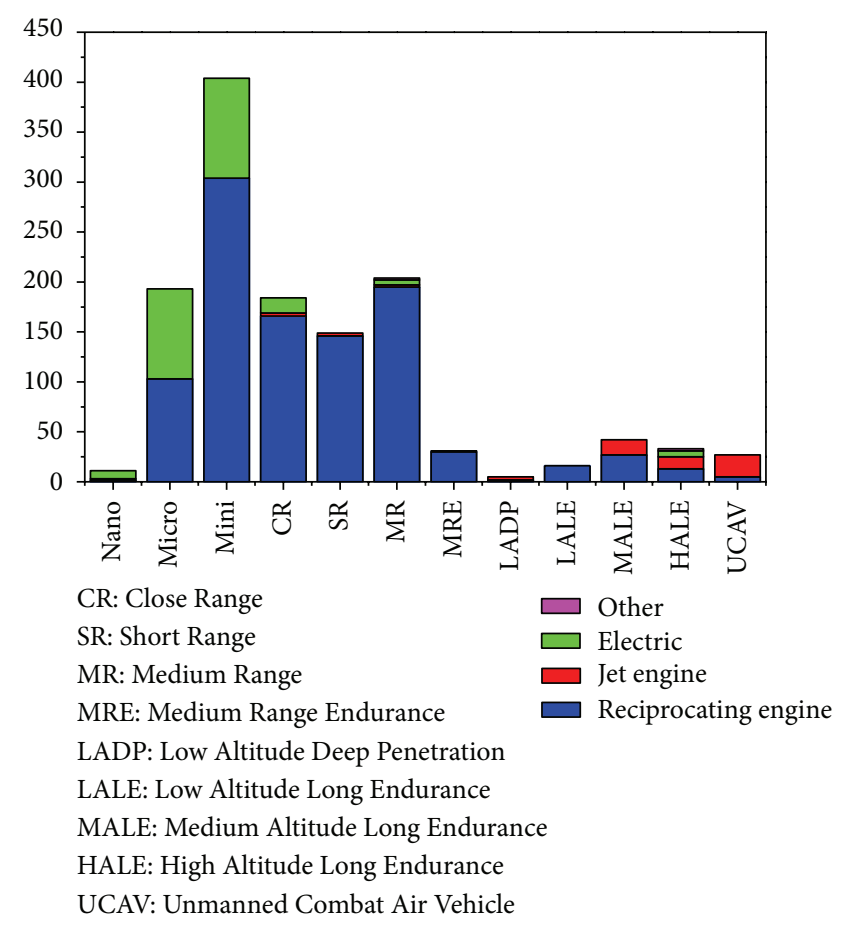

FIGURE 6: UAVs histogram according to sizes and powerplants. "Electric" includes batteries, fuel cells, and solar. "Other" includes rocket propelled, Wankel, laser powered, and hydrogen combustion.

be a need for space saving and, consequently, a subsequent selection of those subsystems.

With regard to electric propulsion systems, batteries are currently limited to $150-200 \mathrm{Wh} / \mathrm{kg}$ and are expected to show an increase of up to $300 \mathrm{Wh} / \mathrm{kg}$ within the next few years; one order of magnitude lower than the specific energy density expected in hydrogen fuel cells [26]. The weight of the electric motor and other auxiliary systems is not included; more information is therefore required in order to properly compare these systems. Unfortunately, since some authors 
and manufacturers do not give out detailed information about these systems, the weight of storage tanks and auxiliary systems, such as control systems, is generally unknown. In the case of tanks and batteries, for a given propulsion system, manufacturers often usually offer different sizes, thus providing different endurance values.

Recent advances in weight saving of electric motors and batteries have allowed for electric propulsion to be more competitive. The main drawback is the low specific energy density of batteries, resulting in large volumes (around four times the equivalent volume of fossil fuels for a given energy). Thus, the problem relies on the endurance of these vehicles.

The breakthroughs in internal combustion engines are focused on downsizing and HCCI technology (Homogeneous Charge Compression Ignition). This technology is based on producing autoignition of a lean and homogeneous mixture (air/fuel ratio $>25$ ) at multiple points in the combustion chamber [26-28].

UAVs are not manned and they typically carry light payloads (e.g., surveillance and communications), so the sum of the propulsion system and the fuel usually exceeds onethird of the total UAV weight, a higher proportion than in conventional aviation [19]. Any slight reduction in the propulsion system weight or in specific consumption can therefore have a significant effect on the endurance increase or the downsizing of the UAV. Current research focuses on the improvement of internal combustion engines and on the use of new energy sources, through fuel cells, for example.

\section{Fuel Cells in Unmanned Aerial Vehicles Propulsion}

3.1. Fuel Cell Fundamentals. Among the most interesting alternative propulsion systems for UAVs are those based on fuel cells. It is still an immature but growing technology, with room for improvement in weight, volume, and cost reduction. Fuel cells are electrochemical systems that convert the chemical energy contained in fuels directly into electric energy. When fed with hydrogen, they produce no greenhouse gases, the only products being water and heat, and the level of noise generation by the engine is low. Water, as well as heat and low oxygen-containing exhaust air, is side product of the fuel cell that could have other applications to compensate the weight disadvantages (particularly in large UAVs), such as water supply for other subsystems, deicing, or inerting of a fossil fuel tank [18]. Unlike batteries, a fuel cell does not need to be recharged; it keeps operating while fuel and oxidizer are supplied from the outside. The fuel cell itself consists of an anode where fuel is injected (usually hydrogen, ammonia, or methanol) and a cathode where an oxidant is introduced (usually air or oxygen), separated by an electrolyte ionic conductor [29]. Usually, fuel cells produce low voltages and must be assembled into a fuel cell stack in order to reach the power required for most UAV applications. Since fuel cells are by their nature modular devices, their power can go from microwatts to megawatts, making them useful in a variety of applications.
The main advantages of fuel cells are their low emissions, high efficiency, modularity, reversibility (this property is exploited in RFC Systems) [30], fuel flexibility, range of applications, low noise, and low infrared signature. However, their disadvantages include cost, sensitivity of the electrode catalyst to poisons, their experimental state, and the lack of $\mathrm{H}_{2}$ availability. In systems powered by reciprocating and jet engines, fuel only contributes to propulsion in $18-25 \%$ of its energy, while in fuel cell powered aircraft this efficiency is in the region of $44 \%$ [31].

3.2. Types of Fuel Cells and Their Suitability for UAVs. Different types of fuel cells exist, differing in the operational temperature range and the electrolyte used. Combining these types of fuel cells with other elements, new concepts emerge, such as, RFC Systems, where the stack uses its reversibility mode as an electrolyzer or as a fuel cell (e.g., Helios UAV/NASA solar power combined with day/night cycles), or hybrid systems, which rely on batteries when more maneuvering power is required [32]. The different characteristics of each type of fuel cell define what application they are most appropriate for. High temperature fuel cells are usually not considered appropriate for UAVs due to their large size and weight, large start time, and the auxiliary systems required to manage the dissipated heat. Nonetheless, there have been some attempts at miniaturizing UAVs, by using a combination of RFC and solar power, suitable for long endurance flights (up to 5 years, project Boeing/DARPA with Solid Oxide Fuel Cell, SOFC [33]).

In addition to the UAVs, general aviation and commercial transport aircraft are possible applications for fuel cells. Several projects like Antares DLR-H2, developed in 2009 by the German Aerospace Center, or the first flight of a manned fuel cell aircraft performed by Boeing's Madrid branch in 2008 are examples of general aviation applications. On the other hand, A320 ATRA and ENFICA-FC [34] are projects that have explored the substitution of commercial aircraft elements like Ram Air Turbine (RAT) or Auxiliary Power Unit (APU) [35].

SOFCs are high temperature fuel cells (above $800^{\circ} \mathrm{C}$ ). The development state of SOFCs is inferior to that of PEMFCs, apart from being heavier. Therefore this paper will focus on PEMFC. However, reforming and cleaning of kerosene for SOFCs are relatively simple [18]. Therefore SOFCs could have interest for future aircraft applications, since kerosene will still be the most important fuel in the next years.

PEM fuel cells operate at low temperature (typically 50 $70^{\circ} \mathrm{C}$ ); the use of polymeric electrolyte provides high current densities. They have a quick start-up, a high specific energy density, and a low specific power density. Therefore, they offer potential advantages for low maneuverability and high endurance UAVs, which is the type of UAV most developed today (mostly used in surveillance applications). The reason is that these properties allow for the development of relatively light, low cost, and reduced volume systems compared to other types of fuel cells [36]. Also, PEM fuel cells have reached a more mature market and several commercial applications already exist $[4,36,37]$. In addition to the aforementioned, 
the efficiency and environmental benefits, low noise, and thermal signature of these cells are invaluable advantages in the military field. The fuel used is hydrogen and can be stored by different means (compression, liquefaction, metal, or chemical hydrides). Hydrogen is usually obtained from natural gas due to economic reasons, but it is also a renewable fuel as it can be produced from water using solar or wind power. Disadvantages of hydrogen include generation costs (it is an energy carrier, not an energy source), the compression/liquefaction costs of storage due to the extra weight and volume needed, and distribution and safety issues like the risk of explosion. Nonetheless, its main advantage is that it has a high heating value and the reaction product is only water and heat.

Direct Methanol Fuel Cell (DMFC) stacks, a class of PEM fuel cells directly fuelled with methanol, have about half the efficiency (higher heat losses) and power density than PEM fuel cells, but higher energy density (greater endurance) and simplicity $[29,36]$. In addition, the storage system is lighter than in the case of hydrogen and the logistics are simpler, potentially able to take advantage of the fossil fuels distribution network. Added to this, the handling and storage of methanol are much more advantageous than that of hydrogen, which requires heavy deposits those must withstand high pressures. Although methanol is toxic, it is not a problem if the appropriate protocols are followed. Another advantage is that it can be obtained from biomass (e.g., wood distillation) and could therefore be considered a renewable fuel [38]. It only emits water and $\mathrm{CO}_{2}$, and if distilled, this is reabsorbed by the biomass produced to generate the new methanol, thus closing the cycle. With costs being lower than for hydrogen, there are already DMFC stacks for terrestrial applications and these could be applied in very light low maneuverability UAVs. The market trend for UAVs is precisely towards miniaturization. Given its low power density and in case of specific requirements of high power demand, DMFC (and PEMFC) will probably need to be combined with hybrid battery systems (except in systems with low power demands, such as airships). Of these, lithiumion batteries are currently the most advanced and developed.

For very small UAVs, compressed hydrogen systems are not practical, since they are not downwardly scalable. In this case, it is preferable to use noncryogenic liquid fuels such as methanol or chemical hydrides, where fuel storage and delivery are considered more critical than the battery performance itself.

Developments in which a fuel cell delivers power to an electric motor, which in turn drives a propeller or a rotor, already exist, such as a helicopter UAV powered by a PEM fuel cell fed with compressed hydrogen. Recent advances in compressed hydrogen powered PEM fuel cells have achieved power densities of up to $1.4 \mathrm{~kW} / \mathrm{kg}$ in the $100 \mathrm{~kW}$ range, although for the $1 \mathrm{~kW}$ range, only $250 \mathrm{~W} / \mathrm{kg}$ is commercially available [14]. These figures lose around another $20 \%$ when the weight of the electric motor is added, leading to final figures worse than other systems. Moreover, the mass of hydrogen, added to its storage system, further worsens the figures with respect to fossil fuels; the data on methanol systems are not so unfavorable regarding the storage system.
However, the energy conversion process is very efficient compared to internal combustion engines and great endurance is achieved. This is due to its high energy density, making them very suitable for long endurance surveillance missions. As an example, the Puma UAV equipped with a Protonex PEM stack flew 9 hours, improving on the 2-hour flight of the same battery-electric UAV [39]. Figure 7 summarizes the possibilities of implementing fuel cell propulsion systems in UAVs.

Auxiliary systems of a fuel cell powered UAV include heat management, humidification system, tanks, and controller. The weight of these systems is very variable and can reach from $14.83 \%$ (UTRC UAV helicopter demonstrator) [14], $43.25 \%$ (Georgia Tech UAV) [40] to $83.33 \%$ (Ion Tiger NRL UAV) [41]. Auxiliary systems consume part of the gross power (about one sixth in the Boeing Fuel Cell Demonstrator manned airplane) [42].

Airships are also a potential new application for fuel cells. There is a rebirth of airships resulting in various studies and prototypes, especially in the field of monitoring and surveillance, where the latest technological advances in materials and navigation are being incorporated [43]. The requirements in the propulsion of airships are relatively modest, being logically higher for takeoff and landing. Due to the buoyancy conferred by helium, they are more energy efficient and cheaper to operate than Heavier-Than-Air (HTA) aircrafts when transporting payloads. Traditionally, they have worked with internal combustion engines, but they are best suited for long flight time in all regimes (including reverse). Nonetheless, they usually run at much lower power than nominal, making them inefficient. In addition, piston engines in airships have lubrication problems [44]. Therefore, electric motors offer good prospects and fuel cells could play an important role. Specifically, DMFC would be suitable for airships because of its long-range and low power density. An example is a Lockheed Martin, High Altitude Airship Project that will operate in a geostationary position above the jet stream (an advantage over combustion engines which exhibit a maximum operating altitude), delivering persistent station keeping as a surveillance platform. A $137 \mathrm{~m}$ length airship with a RFC solar $/ \mathrm{H}_{2} / \mathrm{O}_{2}$ propulsion system would be able to remain 10 years flying and be an alternative to satellites [45]. High Altitude Airship has altitude restriction because the oxidizer is stored onboard. Most fuel cells are however airbreathing to save weight and storage volume and as such also have an altitude restriction.

3.3. Advantages and Disadvantages of Fuel Cells in UAVs. Thus, the advantages of a fuel cell powered electric motor can be summed up as follows:

(i) more efficient than fossil fuel technologies,

(ii) high energy density, which means greater endurance,

(iii) reliability: few moving parts and easy automation,

(iv) flexibility of operation: in that they are reversible, can work at high performance without interruption for a wide range of power demands, and can also rapidly change their power output; anyway, the latest point 


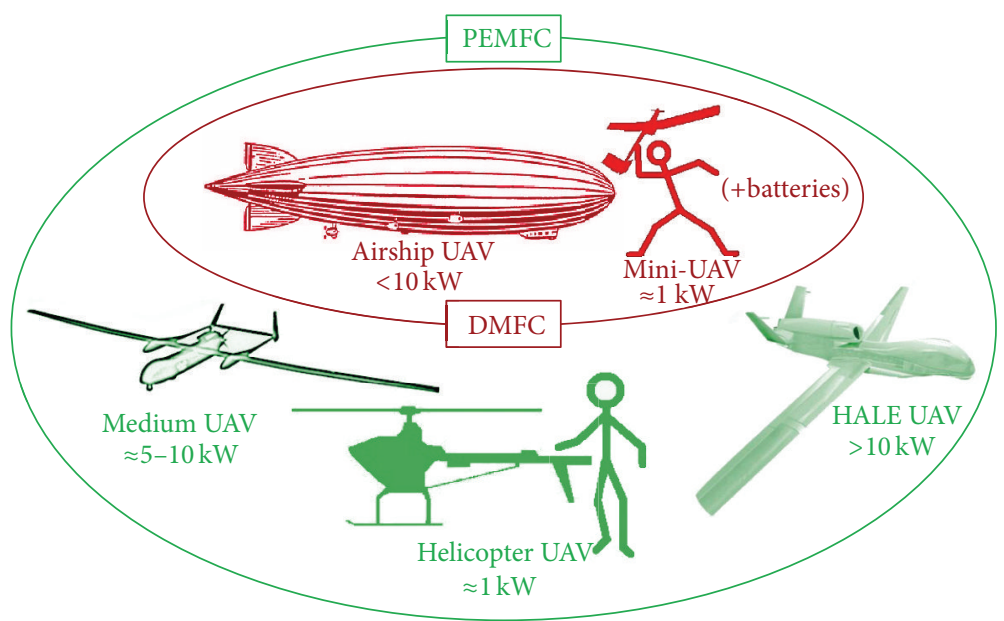

FIGURE 7: Possibilities of implementing fuel cells propulsion systems in UAVs.

is not enough for demanding maneuvers like takeoff, thus the support, with batteries is often necessary,

(v) modular and easy to implement,

(vi) direct energy conversion (no combustion),

(vii) negligible noise and vibration,

(viii) low or zero emissions,

(ix) a variety of applications: in addition to propulsion systems in UAVs, they might be used in APUs, auxiliary power systems, ground control stations, and so forth,

(x) water, as well as heat and low oxygen-containing exhaust air, is side product of the fuel cell that could have other applications to compensate the weight disadvantages (particularly in large UAVs), such as water supply for other subsystems, deicing, or inerting of a fossil fuel tank.

\section{Main disadvantages are}

(i) high cost: it is not yet a mature technology and uses expensive materials like platinum, used as a catalyst,

(ii) sensitivity to fuel contamination, requiring expensive filtering systems,

(iii) the need for qualified maintenance personnel,

(iv) low power density compared to other systems, especially in DMFC stacks,

(v) unavailability of hydrogen: $\mathrm{H}_{2}$, one of the fuels used in fuel cells, is not naturally abundant; it must be obtained through water electrolysis or hydrocarbons reforming, defining it as an energy carrier rather than an energy source; there is also currently no distribution infrastructure,

(vi) unproven reliability for commercial use: there is little "real" commercial fuel cell UAVs and where they exist, their implementation is very recent, and their technology is therefore still far from mature, (vii) safety issues regarding $\mathrm{H}_{2}$ handling (hydrogen gas forms explosive mixtures with air) and methanol toxicity, this fact has influence, for a military setting, on the logistics of the fuel supply in the battlefield.

With the reasons given above, the advantages and disadvantages of a UAV propulsion system based on fuel cells are practically the same as those of the fuel cell stack itself, slightly worsened by the need to add the electric motor and its accompanying weight.

\subsection{Examples in the Market}

Analysis. In Figure 8, power versus weight of PEM and DMFC commercial fuel cells is represented. Tank weight has been included when available. The cases of PEM fuel cells with UAV and general aircraft applications are considered. It can be seen that there are PEM fuel cells that could easily be adapted to UAVs, but no DMFC for UAV application has yet been identified.

The main problem of fuel cells is their low power density, meaning the UAV performance would have restrictions and would be very dependent on its aerodynamic design, weight, and fuel cell performance [46]. This highlights the possible complementary use of batteries to form hybrid systems, especially in the case of DMFC which have these lower power densities. There are no examples found of a UAV powerplant based on a DMFC stack (not even hybrid), only a few experimental developments in their early stages $[47,48]$. There are examples of hydrogen-based PEM UAVs, as already mentioned (10 in 2012 according to UVS [9]), and UAV hybrid projects based on compressed hydrogen PEMs [32]. In Figure 8, the power of commercial fuel cells versus their weight is plotted for three different scales of different UAV application cases. PEMFCs are all located in the left lower corner of Figures 8(a) and 8(b). There is one existing example of a big UAV with a PEM powerplant, the Aerovironment Global Observer, but no technical data were found regarding the powerplant, so it is not shown in figures. Figure 8 also shows that DMFC found in the 


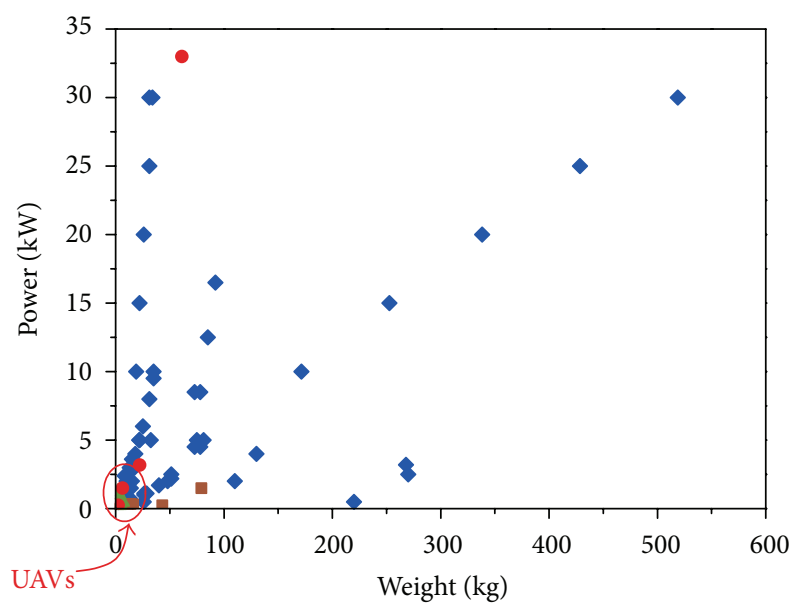

(a)

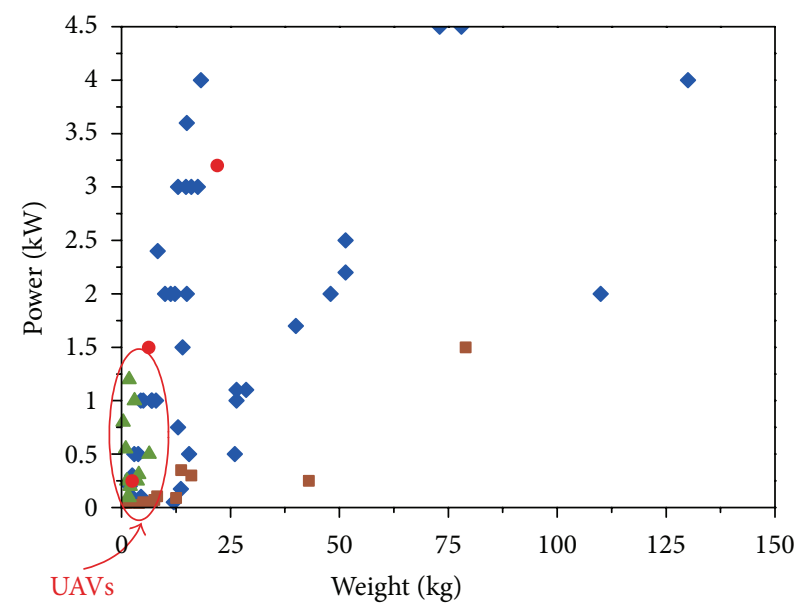

(b)

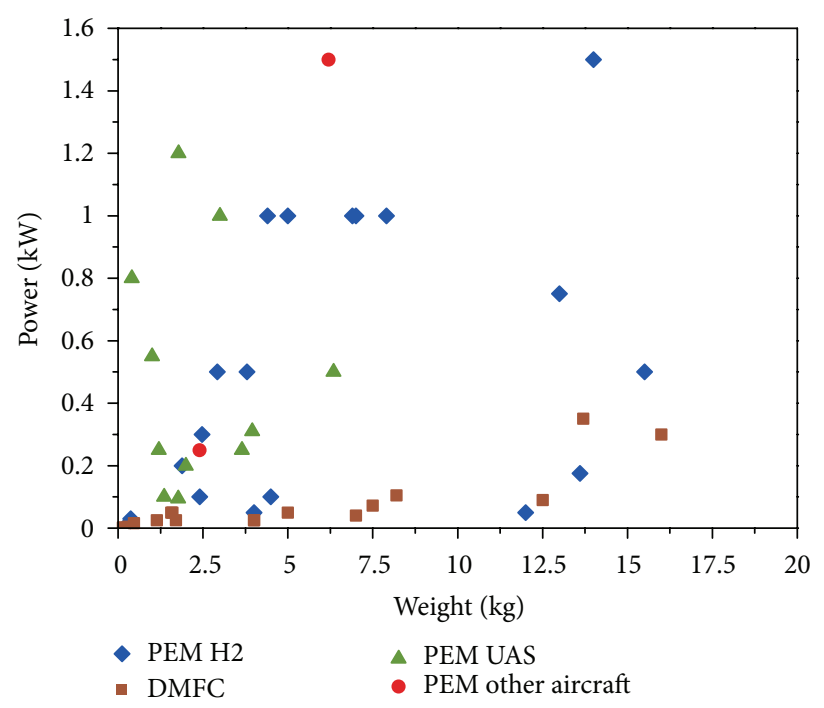

(c)

FIGURE 8: Power versus weight of PEM and DMFC commercial fuel cells.

market have very low power and that, with the current technology, a fuel cell can only be implemented in small UAVs.

Relevant technical data of PEM fuel cells for UAV applications have been collected and summarized and are shown in Table 2 . They are important in order to confirm the viability of fuel cells for UAV powerplants and allow the comparison between different types of fuel storage systems related to the sizes and fuel cell power densities of UAVs.

Nowadays, the specific energy density of a PEM fuel cell system, which implies higher endurance in UAVs, is about $700-1000 \mathrm{Wh} / \mathrm{kg}$, but it is to be increased up to $10 \mathrm{kWh} / \mathrm{kg}$ within the next $10-15$ years and to $20 \mathrm{kWh} / \mathrm{kg}$ within $20-30$ years, which, if achieved, will enable the all-electric flight of a large commercial aircraft [34]. In the case of DMFC cells, the advantage in terms of endurance comes from the methanol storage. The equivalent energy content of 50 gasoline liters is, taking into account the tank mass, $80 \mathrm{~kg}$ of methanol while analogous figure regarding $\mathrm{H}_{2}$ (300 bar compressed) is $442 \mathrm{~kg}$ [49].

Attention should also be paid to the potential performance loss in fuel cells depending on the environmental conditions of the aircraft flight (i.e., changes in pressure/altitude, temperature [50], vibration, humidity, salinity, radiation, shock, etc.). Most fuel cells are designed to work on land, statically, with relatively stable environmental conditions. However, in flight, these conditions change more or less sharply depending on the UAV service ceiling, its speed, airfield location, and so on. The influence on the performance is relevant, since parameters such as humidity will affect the operation of the fuel cell membrane. There is little literature on the influence of environmental conditions on the performance of a UAV $([21,31,50]$, for general aircraft conditions), although the manufacturing company, Horizon 
TABLE 2: Examples of PEM fuel cells for UAV applications.

\begin{tabular}{|c|c|c|c|c|c|}
\hline \multicolumn{6}{|c|}{ Specifications from manufacturers' websites and [18] } \\
\hline Fuel type & Manufacturer/model & $\begin{array}{l}\text { FC weight } \\
(\mathrm{kg})\end{array}$ & $\begin{array}{l}\text { FC power } \\
\text { (W) }\end{array}$ & $\begin{array}{l}\text { FC power density } \\
(\mathrm{W} / \mathrm{kg})\end{array}$ & Application/remarks \\
\hline $\begin{array}{l}\text { Chemical } \\
\text { hydride } \\
\text { cartridge }\end{array}$ & $\begin{array}{l}\text { Horizon Energy } \\
\text { Systems/AEROPAK }\end{array}$ & 3.5 & 200 & 57.14 & $\begin{array}{l}\text { IAI Bird Eye } 650 \text { LE UAV } \\
10 \text { A-21 V nominal. } 600 \mathrm{~W} \text { with LiPo } \\
\text { batteries. Cartridge Type I: } 446 \mathrm{Wh} / \mathrm{kg} \text {. } \\
\text { Type II: } 607 \mathrm{Wh} / \mathrm{kg} . \\
\text { Also used in Bluebird Boomerang } \\
\text { mini-UAV and Elbit Skylark UAV. }\end{array}$ \\
\hline $\begin{array}{l}\text { Sodium } \\
\text { borohydride }\end{array}$ & Protonex/UAV C-250 & 1.2 & 250 & 208.33 & $\begin{array}{l}500 \mathrm{~W} \text { peak power with batteries. Fuel } \\
833 \mathrm{Wh} / \mathrm{kg} \text { hydrated. Cartridge } 1.8 \mathrm{~kg}, 1.5 \mathrm{l} \text {. }\end{array}$ \\
\hline Compressed $\mathrm{H}_{2}$ & $\begin{array}{l}\text { Protonex/Spider Lion UAV } \\
\text { (NRL) }\end{array}$ & 1.77 & 95 & 53.67 & Spider Lion Micro-UAV 2005, 3-hour flight \\
\hline Compressed $\mathrm{H}_{2}$ & $\begin{array}{l}\text { Protonex/Ion Tiger UAV } \\
\text { (NRL) }\end{array}$ & 1 & 550 & 550 & $\begin{array}{l}\text { Ion Tiger UAV. } 550 \mathrm{~W} \text { FC }(1 \mathrm{~kg}+3.6 \mathrm{~kg} \\
\left.\text { tank } 0.5 \mathrm{~kg} \mathrm{H} \mathrm{H}_{2}\right), 26 \mathrm{~h} 1 \mathrm{~m} \text { flight record in } \\
2009 . \\
\text { Powerplant total weight (including fuel } \\
\text { and cooling) }=6 \mathrm{~kg} \text {. Specific energy } \\
1300 \mathrm{Wh} / \mathrm{kg} .26 \mathrm{~h} \text { endurance }\end{array}$ \\
\hline Compressed $\mathrm{H}_{2}$ & EnergyOr/EO-310-XLE & 3.95 & 310 & 78.48 & $\begin{array}{l}\text { Radiant Coral Technologies demonstrator } \\
\text { UAV 1st flight February 25, } 2013 \text {. } \\
\text { Hybrid. The weight includes auxiliary } \\
\text { systems }\end{array}$ \\
\hline Compressed $\mathrm{H}_{2}$ & EnergyOr/EO-210-XLE & 3.65 & 250 & 68.49 & The weight includes auxiliary systems \\
\hline Compressed $\mathrm{H}_{2}$ & DLR/HyFish UAV & 3 & 1000 & 333.33 & HyFish UAV 2007. 0.5 hour flight \\
\hline Compressed $\mathrm{H}_{2}$ & UTRC/Gen1 & 1.78 & 1200 & 674.16 & $\begin{array}{l}\text { Helicopter UAV (October 11, 2009). FC } \\
(675 \mathrm{~W} / \mathrm{kg}) \text {. Powerplant }(500 \mathrm{~W} / \mathrm{kg}) \text {. } \\
\text { Minicopter Maxi Joker. } 20 \mathrm{~m} \text { flight }\end{array}$ \\
\hline Compressed $\mathrm{H}_{2}$ & BCS/BCS500 & 6.35 & 500 & 78.74 & $\begin{array}{l}\text { Georgia Tech University UAV } 2006 . \\
\text { Powerplant weight } 12 \mathrm{~kg}\end{array}$ \\
\hline Compressed $\mathrm{H}_{2}$ & $\begin{array}{l}\text { Horizon Energy } \\
\text { Systems/H-100 }\end{array}$ & 1.36 & 100 & 73.53 & Johannesburg University Piper Cub UAV \\
\hline $\begin{array}{l}\text { Sodium } \\
\text { borohydride }\end{array}$ & Protonex/ProCore VI & 0.408 & 800 & 1960.78 & $\begin{array}{l}\text { Aerovironment Puma UAV } 2008 . \\
\text { Endurance } 9 \mathrm{~h}\end{array}$ \\
\hline Compressed $\mathrm{H}_{2}$ & $\begin{array}{l}\text { Horizon Fuel Cell } \\
\text { Technologies }\end{array}$ & 5 & 650 & 130 & $\begin{array}{l}\text { Pterosoar micro-UAV 2008. Oklahoma } \\
\text { State and California State Universities. } \\
15.5 \text { h endurance. FC } 480 \mathrm{Wh} / \mathrm{kg}\end{array}$ \\
\hline Liquid $\mathrm{H}_{2}$ & $\begin{array}{c}\text { NASA/Sensor } \\
\text { Technology/Aerovironment }\end{array}$ & - & - & - & $\begin{array}{l}\text { Aerovironment Global Observer (GO-1). } \\
65,000 \mathrm{ft} \text { alt., 7-day endurance. PL } 180 \mathrm{~kg}\end{array}$ \\
\hline
\end{tabular}

Energy Systems, has published data on its technical specification sheets, (UAV Aeropak fuel cell, $200 \mathrm{~W}$, metal hydride cartridge [51]).

\section{Conclusions}

Could the feasibility to implement a fuel cell in a UAV be asserted? The short answer is yes although, obviously, not for all combinations of fuel cells and UAVs. From the study carried out in this work, the following conclusions can be drawn.

(i) Fuel cell technology is still immature but improving, with clear room for improvement in weight, volume, and costs reductions. Compared with conventional systems, fuel cells offer higher energy density and lower specific power density. (ii) Fuel cells offer potential advantages in low maneuverability UAVs, which are currently the most manufactured type (e.g., surveillance applications), and in high endurance operations.

(iii) PEM fuel cells have reached a more mature market. The facts of being of low temperature and having a fast start-up time are features consistent with the requirements of most UAVs. Reforming other fuels (e.g., natural gas, gasoline, etc.) remains an uninteresting option because the weight and volume of the reformer would need to be added. A jet fuel reformer could only be assessed in the case of large UAVs [31].

(iv) There are different fuel storage systems for each type of fuel cell. Therefore, in the case of a UAV, it is essential to minimize the weight of the overall propulsion 
system (fuel cell/storage system) without forgetting to consider the weight of auxiliary systems, such as thermal control or water management systems.

(v) Several commercial UAV applications of PEM hydrogen fuel cells already exist. There is even an example of a fuel cell powered UAV rotorcraft (demonstrator, [14]). In most of these cases, the target is small size UAVs. Nonetheless, some fuel cell manufacturers already offer fuel cells designed for a general type of UAV and on the other hand there are UAV manufacturers that have developed a UAV specifically designed to accept a fuel cell based powerplant.

(vi) Compared to hydrogen and despite its toxicity which is not an important problem following the proper protocols, methanol has advantages in terms of its storage systems, especially with logistics, in energy density and cost, and even in safety issues. DMFC fuel cell systems have less power density in comparison to other types of fuel cells, but higher energy density. The possibility of implementing DMFC stacks in UAVs is considered an interesting alternative and left for future work.

(vii) Airship propulsion requirements are relatively modest, being the greatest for takeoff and landing. Electric motors offer good prospects with respect to the currently used internal combustion engines, and consequently fuel cells can play an important role. Specifically, DMFC would be suitable for airships because of its long-range and low power density.

(viii) Since the low power density is the main problem of fuel cells, hybridization with electric batteries would be necessary in most cases.

\section{Acronyms}

$\begin{array}{ll}\text { APU: } & \text { Auxiliary Power Unit } \\ \text { CR: } & \text { Close Range } \\ \text { DARPA: } & \text { Defense Advanced Research Projects Agency } \\ \text { DC: } & \text { Direct Current } \\ \text { DMFC: } & \text { Direct Methanol Fuel Cell } \\ \text { ENFICA: } & \text { Environmentally Friendly Intercity Aircraft } \\ \text { FC: } & \text { Fuel cell } \\ \text { HALE: } & \text { High Altitude Long Endurance } \\ \text { HCCI: } & \text { Homogeneous Charge Compression Ignition } \\ \text { HTA: } & \text { Heavier-Than-Air } \\ \text { LADP: } & \text { Low Altitude Deep Penetration } \\ \text { LALE: } & \text { Low Altitude Long Endurance } \\ \text { MALE: } & \text { Medium Altitude Long Endurance } \\ \text { MR: } & \text { Medium Range } \\ \text { MRE: } & \text { Medium Range Endurance } \\ \text { MTOW: } & \text { Maximum Takeoff Weight } \\ \text { NASA: } & \text { National Aeronautics and Space } \\ & \text { Administration } \\ \text { NRL: } & \text { Naval Research Laboratory } \\ \text { PEM: } & \text { Proton Exchange Membrane, Polymer } \\ & \text { Electrolyte Membrane }\end{array}$

PEMFC: Proton Exchange Membrane Fuel Cell, Polymer Electrolyte Membrane Fuel Cell

P/L: Payload

RAT: Ram Air Turbine

RFC: Regenerative Fuel Cell Systems

SOFC: $\quad$ Solid Oxide Fuel Cell

SR: $\quad$ Short Range

STRA: Stratospheric

UAS: Unmanned Aerial System

UAV: Unmanned Aerial Vehicle

UCAV: Unmanned Combat Aerial Vehicle

US: $\quad$ United States

UTRC: United Technologies Research Center

UVS: Unmanned Vehicle Systems.

\section{Conflict of Interests}

The authors declare that there is no conflict of interests regarding the publication of this paper.

\section{Acknowledgments}

This work has been partially supported by the Spanish Ministerio de Ciencia y Tecnología in the framework of Project codes ENE2007-67584-C03-03ALT and ENE201128735-C02-02. The authors would also like to thank Mr. Hugo Gee for his careful reading of the paper.

\section{References}

[1] S. Wezeman, "UAVs and UCAVs: Developments in the European Union," http://www.europarl.europa.eu/RegData/etudes/ etudes/join/2007/381405/EXPO-SEDE_ET\%282007\%29381405 _EN.pdf.

[2] L. G. Freire Bouillon, Perfiles IDS: Sistemas Aéreos no Tripulados (UAS), IDS, Madrid, Spain, 2009.

[3] D. Maple, M. G. Sánchez Jiménez, J. M. Sanjurjo Jul, and C. Calvo González-Regueral, Perfiles IDS: Sistemas no Tripulados, IDS, Madrid, Spain, 2012.

[4] M. F. Hordeski, Hydrogen \& Fuel Cells: Advances in Transportation and Power, The Fairmont Press, Lilburn, Ga, USA, 2009.

[5] E. Navarro Arévalo, O. Mosquera, and A. di Bernardi, "Diferentes opciones de propulsión para una futura aviación general con sensibilidad ambiental," in 2nd Congreso Argentino de Ingeniería Aeronáutica, Córdoba, Argentina, November 2010.

[6] O. González-Espasandin, T. J. Leo, and E. Navarro, "Fuel cells: alternative propulsion for unmanned aerial vehicles," in Proceedings of the Workshop on Research, Development and Education on Unmanned Aerial Systems (RED-UAS '11), Sevilla, Spain, November-December 2011.

[7] Intergovernmental Panel on Climate Change (IPCC), Climate Change 2007: Synthesis Report, IPCC, Geneva, Switzerland, 2013, http://www.ipcc.ch/publications_and_data/publications_ipcc_fourth_assessment_report_synthesis_report.htm.

[8] U.S. Department of Energy, Transportation Energy Data Book, 2010, http://cta.ornl.gov/data/index.shtml.

[9] UVS International, "Remotely piloted aircraft systems in development/production," in UAS Unmanned Aircraft Systems Yearbook: The Global Perspective, pp. 156-192, Blyenburgh, 
Paris, France, 10th edition, 2012, http://uvs-info.com/index .php? option $=$ com_flippingbook\&view $=$ book\&id $=13$ \&page $=1 \&$ Itemid $=686$.

[10] Honeywell, http://www.honeywell.com/sites/aero/Phoenix Repair_Overhaul3_C5D5EB8A7-6730-18D1-H9AEA1D8BBF41-B3D4-D125-071C246FE7BB.htm.

[11] Pratt \& Whitney, http://www.pwc.ca/en/engines/pw535b.

[12] ElectriFly, http://www.electrifly.com/motors/gpmg4505.html.

[13] A123 Systems, http://www.a123systems.com/lithium-ion-cells26650-cylindrical-cell.htm.

[14] D. E. Parekh, Fuel Cell Revolution, Aerospace Testing International, 2010.

[15] J. Baldic, P. Osenar, N. Lauder, and P. Launie, "Fuel cell systems for long duration electric UAVs and UGVs," in Defense Transformation and Net-Centric Systems 2010, vol. 7707 of Proceedings of SPIE, April 2010.

[16] S. Surampudi, Overview of the Space Power Conversion and Energy Storage Technologies, NASA-Jet Propulsion Laboratory, Pasadena, Calif, USA, 2011, http://www.lpi.usra.edu/sbag/ meetings/jan2011/presentations/dayl/d1_1200_Surampudi.pdf.

[17] O.S. Engines, http://www.osengines.com/engines-airplane/ osmg1401/index.html.

[18] C. Roessler, J. Shoemann, and H. Baier, "Aerospace applications of hydrogen and fuel cells," in Hydrogen and Fuel Cells, D. Stolten, Ed., pp. 661-680, Wiley-VCH, Weinheim, Germany, 2010.

[19] R. Austin, Unmanned Aircraft Systems: UAVs Design, Development and Deployment, John Wiley \& Sons, Chichester, UK, 2010.

[20] J. Y. Hung and L. F. Gonzalez, "On parallel hybrid-electric propulsion system for unmanned aerial vehicles," Progress in Aerospace Sciences, vol. 51, pp. 1-17, 2012.

[21] T. Hordé, P. Achard, and R. Metkemeijer, "PEMFC application for aviation: experimental and numerical study of sensitivity to altitude," International Journal of Hydrogen Energy, vol. 14, pp. 10818-10829, 2011.

[22] Massachusetts Institute of Technology, "Efficiencies of $\mathrm{A} / \mathrm{C}$ Engines," http://web.mit.edu/16.unified/www/SPRING/propulsion/UnifiedPropulsion3/UnifiedPropulsion3.htm.

[23] Stanford University, Aircraft Aerodynamics and Design Group, http://adg.stanford.edu/aa241/propulsion/smallfan.html.

[24] G. A. Misté and A. Benini, "Performance of a turboshaft engine for helicopter applications operating at variable shaft speed," in Proceedings of the ASME Gas Turbine India Conference, December 2012.

[25] Aerospace Blog, "TCM Reveals SFC of Jet-A-Burning Piston," 2010, http://aerospaceblog.wordpress.com/2010/05/20/continental-motors-reveals-jet-a-burning/.

[26] A. Albrecht, O. Grondin, and G. Corde, "HCCI diesel engine control design," AutoTechnology, vol. 7, pp. 60-63, 2007.

[27] H. Blaxill and A. Cairns, "Production-feasible controlled autoignition," AutoTechnology, vol. 7, pp. 28-31, 2007.

[28] A. Kulzer, A. Kufferath, A. Christ, J.-P. Hathout, M. Knopf, and K. Benninger, "Controlled auto-ignition," AutoTechnology, vol. 7, no. 4, pp. 56-59, 2007

[29] J. Larminie and A. Dicks, Fuel Cell Systems Explained, John Wiley \& Sons, Chichester, UK, 2nd edition, 2003.

[30] G. Romeo, M. Pacino, and F. Borello, "First flight of scaled electric solar powered UAV for Mediterranean Sea border surveillance forest and fire monitoring," The Journal of Aerospace Science, Technology and Systems, vol. 88, no. 1-2, pp. 8-19, 2009.
[31] G. Renouard-Vallet, M. Saballus, G. Schmithals, J. Schirmer, J. Kallo, and K. A. Friedrich, "Improving the environmental impact of civil aircraft by fuel cell technology: concepts and technological progress," Energy and Environmental Science, vol. 3, no. 10, pp. 1458-1468, 2010.

[32] M. K. Fürrutter and J. Meyer, "Small fuel cell powering an unmanned aerial vehicle," in Proceedings of the IEEE AFRICON Conference, pp. 1-6, Nairobi, Kenya, September 2009.

[33] Fuel Cell Today, http://www.fuelcelltoday.com/news-events/ news-archive/2010/december/versa-power-wins-boeingdarpacontract-to-supply-sofc-for-uav.

[34] G. Romeo, F. Borello, G. Correa, and E. Cestino, "ENFICA-FC: design of transport aircraft powered by fuel cell \& flight test of zero emission 2-seater aircraft powered by fuel cells fuelled by hydrogen," International Journal of Hydrogen Energy, vol. 38, pp. 469-479, 2013.

[35] J. W. Pratt, L. E. Klebanoff, K. Munoz-Ramos, A. A. Akhil, D. B. Curgus, and B. L. Schenkman, "Proton exchange membrane fuel cells for electrical power generation on-board commercial airplanes," Applied Energy, vol. 101, pp. 776-796, 2013.

[36] A. Léon, Hydrogen Technology: Mobile and Portable Applications, Springer, Berlin, Germany, 2008.

[37] Nuvera Fuel Cells, http://www.nuvera.com/.

[38] T. S. Zhao, K. Kreuer, and T. van Nguyen, Advances in Fuel Cells. Volume 1, Elsevier, Oxford, UK, 2007.

[39] Ares: A Defense Technology Blog, "Fuel Cell-Powered HandLaunched UAV Flies for Nine Hours," 2008, http://www .aviationweek.com/Blogs. aspx? plckBlogId = Blog:27ec4a53dcc8-42d0 -bd3a-01329aef79a7 \&plckPostId = Blog:27ec4a53dcc8-42d0-bd3a-01329aef79a7Post:6cdb0db8-a31c-48d0-8ea9f0cdclbaf279.

[40] T. H. Bradley, B. A. Moffitt, R. W. Thomas, D. Mavris, and D. E. Parekh, Test Results for a Fuel Cell-Powered Demonstration Aircraft, Publication no. 2006-01-3092, SAE, 2006.

[41] K. Swider Lyons, Fuel Cell Propulsion for Small Unmanned Air Vehicles: The Ion Tiger, Naval Research Laboratory, http:// www.aps.org/units/gera/meetings/marchl0/upload/SwiderLyonsAPS3-14-10.pdf.

[42] N. Lapeña-Rey, J. Mosquera, E. Bataller, and F. Ortí, “The boeing fuel cell demonstrator airplane," Tech. Rep. 2007-01-3906, SAE International, Warrendale, Pa, USA, 2007.

[43] G. Jennings, "Staying power," Jane's Defence Weekly, vol. 48, no. 45-48, 2011.

[44] M. Streetly and N. Brown, "Eyes down: at last a viable role for airships?" in Jane's International Defence Review, vol. 43, pp. 5255, Coulsdon, Surrey, UK, 2010.

[45] Lockheed Martin, http://www.lockheedmartin.com/us/products/lighter-than-air-vehicles/haa.html\#.

[46] T. H. Bradley, B. A. Moffitt, D. N. Mavris, and D. E. Parekh, "Development and experimental characterization of a fuel cell powered aircraft," Journal of Power Sources, vol. 171, no. 2, pp. 793-801, 2007.

[47] QuantumSphere Inc., http://www.qsinano.com/news/newsletters/2009_11/2009_11.php.

[48] K. McGrath and J. Chrostowski, "Direct methanol fuel cells for UAV propulsion," in Proceedings of the Microtech Conference \& Expo, Nano Science and Technology Institute, Anaheim, Calif, USA, 2010.

[49] G. Hoogers, Ed., Fuel Cell Technology Handbook, CRC Press, Boca Raton, Fla, USA, 2003. 
[50] S. Bégot, F. Harel, D. Candusso, X. François, M.-C. Péra, and S. Yde-Andersen, "Fuel cell climatic tests designed for new configured aircraft application," Energy Conversion and Management, vol. 51, no. 7, pp. 1522-1535, 2010.

[51] Horizon Energy Systems, http://www.hes.sg/files/AEROPAK_ Technical_Data_Sheet.pdf. 

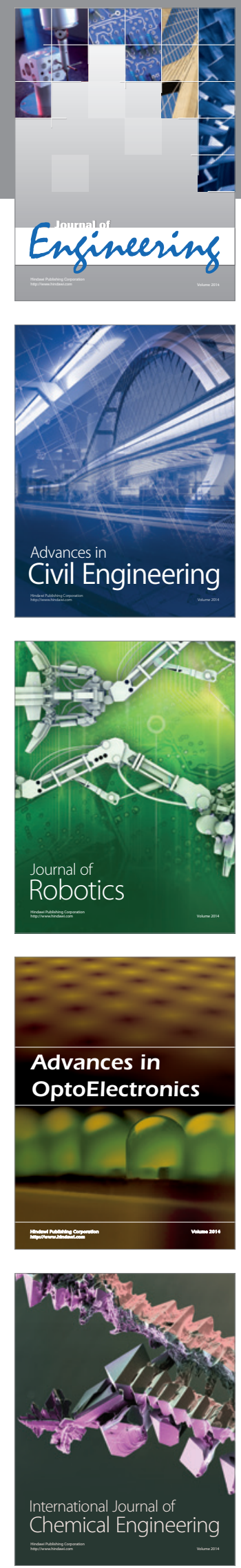

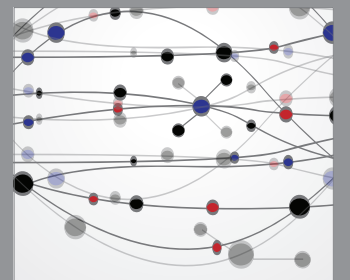

The Scientific World Journal
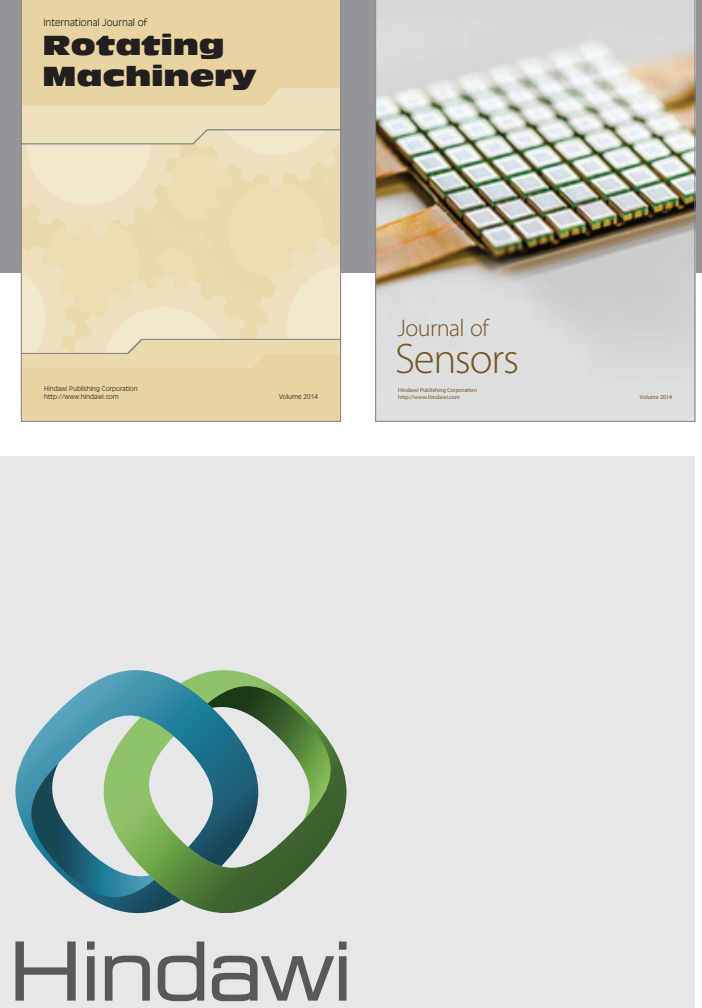

Submit your manuscripts at http://www.hindawi.com
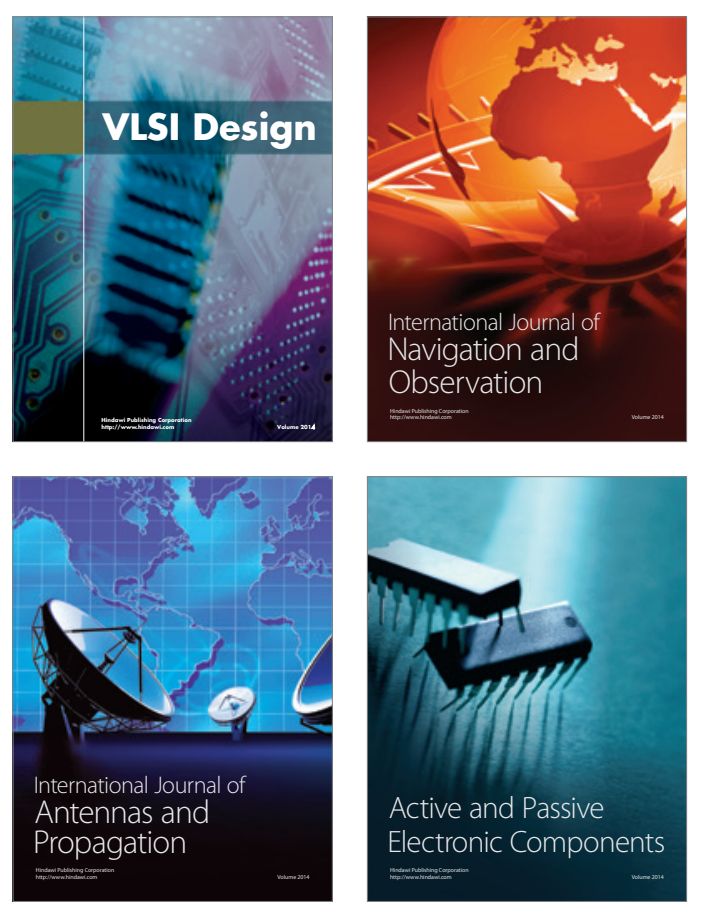
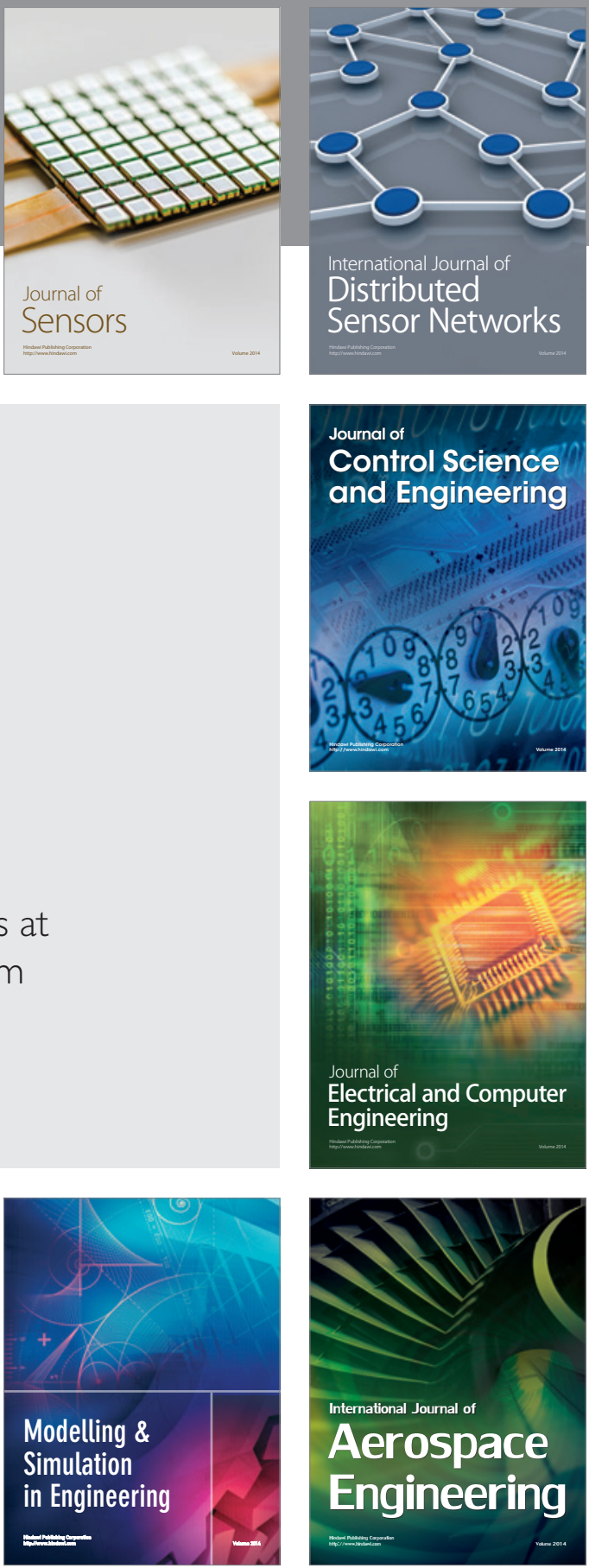

Journal of

Control Science

and Engineering
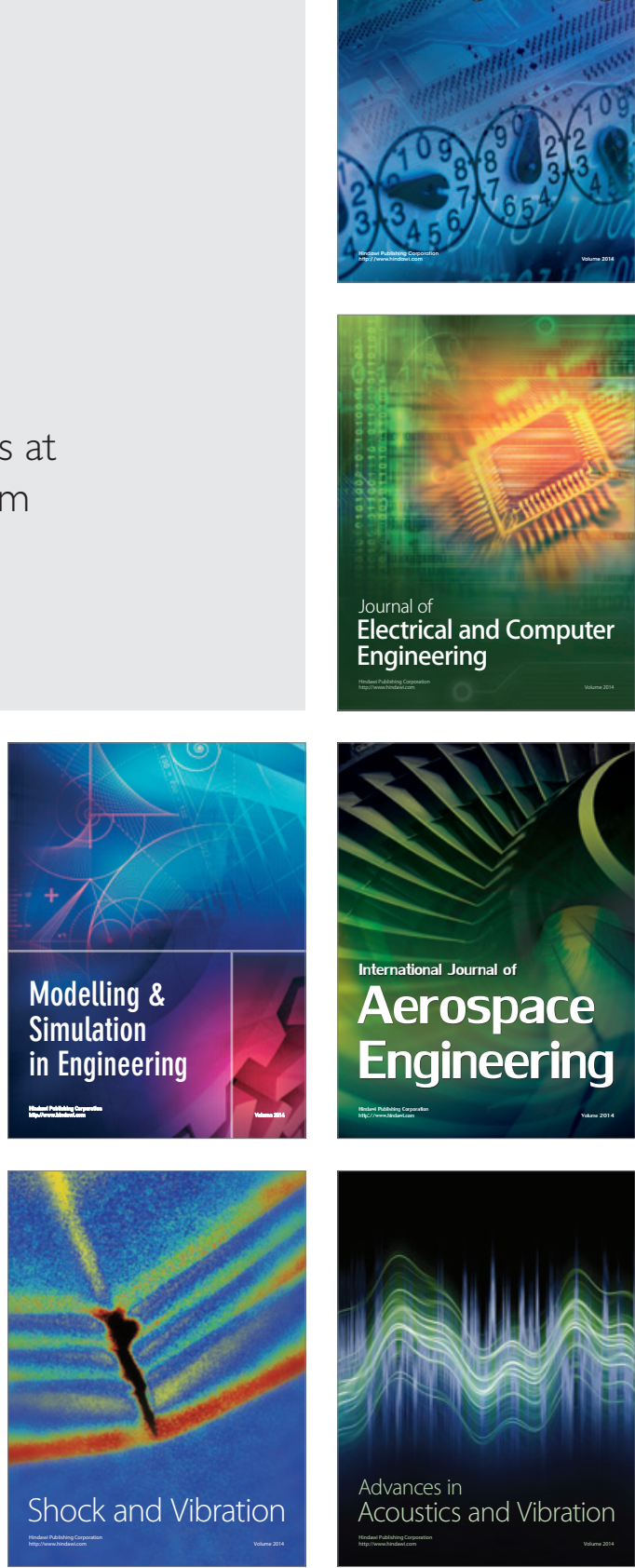